worker informed of new work and of developments in his field and the difficulty of minimizing the unnecessary duplication of research, the Council set up a Working Party on Scientific Information. This Working Party was charged with investigating the whole problem of the collection, dissemination and retrieval of information in the field of electronies and making recommendations. Assessing the magnitude of the problem by estimating the annual output of papers and reports of significance to electronice research workers and judging the effectiveness of the published abstracts journals in making the information available, the Working Party concluded that fully published material was satisfactorily indexed for retrospective searching, but that 'semi-published' material (research reports) was poorly served by published indexes. The situation was even less satisfactory in relation to what has been termed 'current awareness'. A research worker trying to make a comprehensive review might have to scan each month more than ten abstracts journals and title lists. Deciding that 'current awareness information' was the most pressing problem the Working Party recommended the investigation of a system of selective dissemination of information in the field of electronics. This system (S.D.T.), which has been in operation in the United Statos for some years, provides on a large scale a 'personal' current awareness information service to individuals or to groups. In its mechanized form the system matches automatically the coded requirements of the user with a similarly coded index of periodical articles, reports and conference papers. There is provision in the system for 'feedback', by which the user assesses the relevance of the information he receives from the computer to his actual needs.

The Council proposed to the Department of Scientific and Industrial Research-now the Science Research
Council-a three-year project to investigate the effective. ness of a computer-based system of S.D.I. for electronics research workers and has asked for financial support. It is pointed out that this project, although confined to the electronies industry, would provide information relevant to any branch of science and technology and thus be of national interest.

The Projects Committee of the Council, under the chairmanship of Sir Gordon Radley, has reviewed the field in order to identify the areas in which a new or sustained research effort is required. Although no conclusions have, as yet, been reached, it is noted that particular attention is being directed to the following five topics: (1) submillimetric waves; (2) non-linear acoustics; (3) highly directive beams at low frequencies; (4) biological sensors and control systems; (5) basic methods of preparation of now electronics materials.

A short article deals with co-operation between the National Electronics Research Council and the Medical Research Council with which there is a large area of common interest in medical electronic instrumentation and equipment. The White Fish Authority has a substantial group of electronic research problems and has invited the assistance of the National Electronics Research Council. A further short article describes the proposed development programme.

Under the heading "Electronics Research in British Universities" is an article dealing with the Department of Electronic and Electrical Engineering of the University of Birmingham. The article, which is the first of a series covering individual university departments, utilizes information collected in a survey carried out in 1963 by the Research Committee of the British Institution of Radio Engineers, now the Institution of Electronic and Radio Engineors.
J. Greig

\title{
TANNING IN THE UNITED STATES TO 1850
}

$\mathrm{T}$ HE manufacture of leather is now only a minor industry in all advanced countries, although still important for fulfilling many specialized neods, including shoe manufacture. For some twenty years or more it has been threatened in a number of areas by competition from synthetic products. In the United States to-day thero is a surplus of hides in excess of the requirements of the leather industries, although the world need for leather is greater than the supply.

In the period to which P. C. Welsh refers in his book, Tanning in the United States to 1850 *, leather was, in contrast, one of the major industries, providing material for harness, saddles, boots and shoes, carriage parts, clothes, gloves, textile machinery and many other essential uses. No substitute was available, so that newly founded colonial communities had rapidly to set up their own tanning facilities, using local tanning materials and local hides. Records of firms, as woll as the material remains of the tanneries, are rapidly disappearing. Amalgamation and competition have eliminated large numbers of tanneries and the records are raroly preserved. It is therefore especially valuable to have Mr. Welsh's carefully documented account of certain aspects of the American industry in the period up to 1850 .

There is ample evidence to show tho widespread distribution of tanneries in the settled areas of tho eastern seaboard, where cattle hides and woolskins were available, by the middle of the seventeenth century. A number of official measures were passod to protect the craft of tanning as well as to attempt to secure good quality in the finished

* Museum of History and Technology, Smithsonian Institution. Tanning in the United States to $1850-a$ Brief History. By Peter C. Welsh. Pp. leather. The manufacturing processes relied almost entirely on manual labour and manual skill, although horses were used for the bark grinding mills. The industrial revolution and the impact of science left the processes almost untouched, up to 1850 and beyond. Even the genius of Sir Humphrey Davy who, in 1802, lectured on tanning, failed to make any impact on the actual processes used. In the absence of mechanization, the uses of steam power in the industry were so limited as to create little demand for the installation of steam engines.

The book provides, by quotation, summary and illustration, an accurate picture of the industry and its processes in this period, together with a detailed account of the various attempts at innovation. These included a successful splitting machine which gave split hides, and the Iess immediately successful French process of Armand Seguin (1794), which aimed at reducing the time of tanning from one to two years to days or at most weeks.

The most detailed section of the book gives an account of the tanneries of Delaware and especially the founding in 1816 of the tanning firm of A. Cordon and Company, through the initiative of the du Pont family, on a site close to their powder factory and eloth mills on the Brandywine. It was intended to exploit the technical ideas originating from the Seguin process, which were expected to givo considerable commercial advantages over the normal slow proecss. Alexandre Cordon de Sandrans had gone to the United States in 1815 as secretary to du Pont de Nemour, and it was he who managed the tannery. The leather from the shorter process does not appear always to have been of satisfactory standard and the commercial management by Cordon was not adoquate to the problems involved. The period was one of low 
prices for finished leather and of high raw material costs (hide and bark). There was no room for the progressive methods, based on expanding demand, which had succoeded in the other du Pont onterprises. By 1825 the firm was finished commorcially and by 1830 it had boen wound. up, with the du Pont compuny bearing the loss.

$\mathrm{H}$ ad the du Pont tannery been founded in a buoyant, period for the loather industry and one in which it was ripe for technical chango, du l'ont might to-day occupy tho leading position in the Unitod States leather industry. In contrast, this company is now launching a synthetic upper leather substitute, 'Corfam', based on oxtonsivo rosearch into the problems of simulating leather's unusual properties. It remains to be soen whother this second attempt to apply seience to making leather-like materials will succeed.

The book is of importance to lanners and to industrial historians and will perhaps lead to further investigntions in other areas to fill out tho many gaps in the industrial history of leather. One or two small technical slips in no way mar the evidont wuthenticity of the pieture given of tho industry and its changes.

A. G. WARD

\section{BASE COMPOSITION OF NONSENSE CODONS IN E. coli \\ EVIDENCE FROM AMINO-ACID SUBSTITUTIONS AT A TRYPTOPHAN SITE IN ALKALINE PHOSPHATASE}

\section{By MARTIN G. WEIGERT and PROF. ALAN GAREN}

Department of Molecular Biology and Biophysics, Yale University, New Haven, Connecticut

\begin{abstract}
CERTAIN mutations produce a codon which uppears $G$ incapable, in somo strains of $E$. coli, of coding for any amino-ncid. Such a mutation, first identified in $T 4$ phage and $E$. coli',2, is called a 'nonsense mutation', and the resulting codon a 'nonsense codon'. A nonsenso mutation drastically alters the normal course of protein synthesis, by blocking the complete synthesis of the polypeptide ehain specified by the gone in which the mutation occurs ${ }^{3}$. A codon which is nonsonse in one strain of E. coli may code for an amino-acid in another strain if an appropriate suppressor gene is prosent ${ }^{1-4}$.

In this article we present evidence on the base composition of a nonsonse codon. This evidence consisists of differont umino-acid substitutions which oceur at one position in the alkalino phosphataso molecule as a result of reversions of a nonsenso mutation in the phosphataso structural gene. We find that the codon assignments reportod for these amino-acids ${ }^{5}$ enn be related by single base changos only to $a$ nonsense codon with the RNA base composition UAG.
\end{abstract}

The procedure for isolating phosphatase-positive revertants from phosphatase-negative nonsense mutants has been reported elsewhere 4 . Mutagenesis with sthyl methane sulphonate (EMS) was performed by sprearing about $10^{\circ}$ mutant cells on agar plates containing a medium selective for phosphatase-positive rovertants and placing a small drop of the mutagen on the plate 4 (this procedure was developed by Drs. C. Levinthal and E. Lin). After incubation for 3 days at $37^{\circ} \mathrm{C}$, rovortant colonies appeared in a cluster surrounding the mutagen spot. For mutagenesis with $N$-methyl- $N^{\prime}$-nitro- $N$-nitrosoguanidine, the same procodure was used, except that a drop of a saturated solution of this mutagen (instead of EMS) was appliod to the agar plate. For nitrous acid mutagencsis, the cells wero treated for $35 \mathrm{~min}$ at $37^{\circ} \mathrm{C}$ in a solution of acetate buffer at $p \mathrm{H} 5.0$ contuining $0.1 \mathrm{M}$ sodium nitrite, after which the cells were grown overnight in nutriont broth and plated for revertants.

The procedures for purifying alkaline phosphatase, for finger-printing its tryptic peptides, and for determining

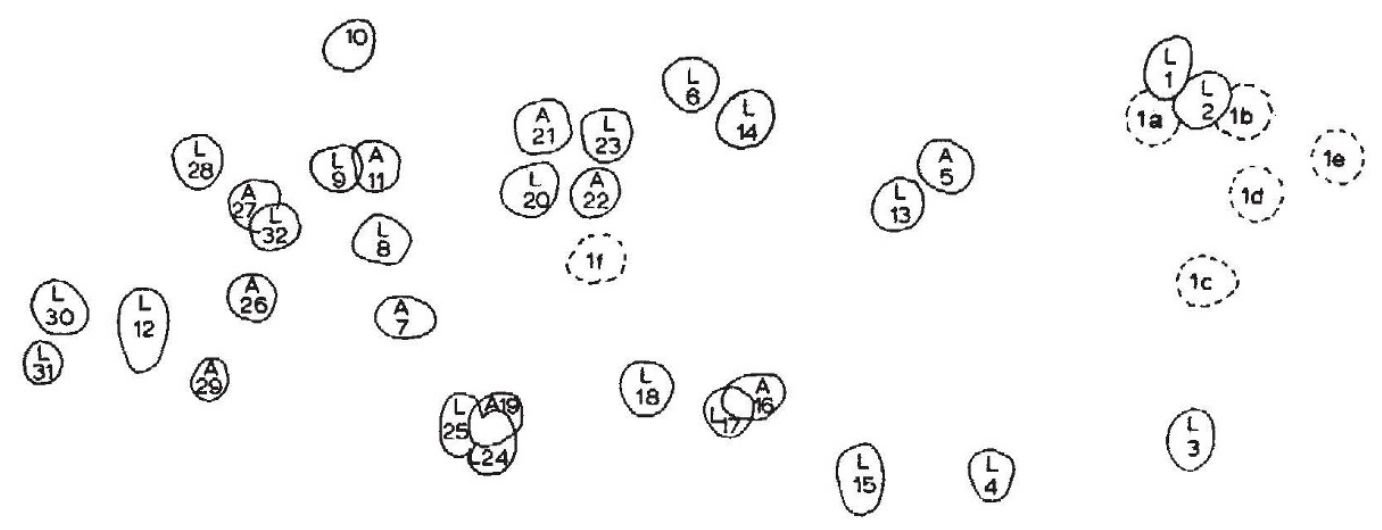

Fig. 1. Fingerprint pattern for tryptic peptides of alkalino phosphatase protein. The sample was applied as a 2-in. strip at the lower left. hand part of tho tilter paper. Electrophoresis was performed at $p \overline{\mathrm{H}} 4 \cdot 7$, followed by chromatography in a perpend leular direction, as degeribed

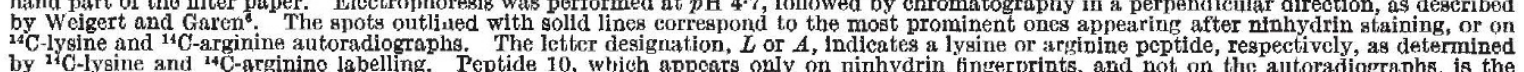

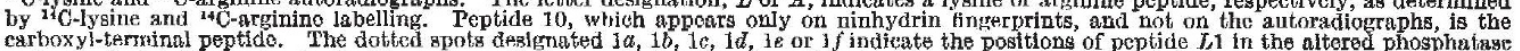
carboxyl-terminal peptide. The datted spots designated $i a, 1 b, 1 c, 1 d, 1 e$ or $1 f$ indicate the positions of peptide $L 1$ in the altered phosphatiase residue (Table 1): 1a, tyrosine; $1 b$, leucine; 1 e, glutamine; $1 d$, serlne; le, lysine or arginine (the shifted pentide does not contain the new basic resil iue since it was released as a free amino-acid by trypsin, as described in Table I); $1 f$, glutamic acid 